\title{
Rute Pardal, As elites de Évora ao tempo da dominação filipina. Estratégias de controlo do poder local (1580-1640), Lisbon, Edições Colibri - Cidehus, Universidade de Évora, 2007, 212 p., ISBN : 978-972-687-5.
}

This volume is in its essence the extended version of Rute Pardal's master's dissertation submitted to the University of Évora in 2003. As the author states in the introduction, to select the theme posed inevitable difficulties given the scarcity of documental material for the period under study.

However, the study is thorough and the author has demonstrated a methodical and careful research carried out on the two institutions that at the time of the Philippine domination detained and controlled power in Évora, namely, the Câmaras and the Misericórdias. The interconnection between these two institutions and the control of local power they exerted through their elite members, was first noticed by Charles Boxer in a study published in 1969 where he mentions a popular dictum in the Alentejo region, which summarises succinctly the influence they exerted through the process of cursus honorum practiced among the members of these two institutions: "who is not in the Câmara is in the Misericórdia".

The author's research is impressive for the amount of substantiated references to existing works dealing with the period under study and although the period spans only sixty years, this study has the advantage of not treating the subject as a static reality but its author travels back and forth into time in order to give the reader a sense of direction in this specialised subject. As a result, what could have been a very dry and tedious subject becomes accessible to a wider readership.

What probably would add more substance to this study would be a clearer statement regarding the state of the Portuguese monarchy under the Habsburgs. The absorption of the Portuguese crown into the Spanish monarchy following the crisis created in the battlefield of Alcácer Kibir was the inevitable outcome, since there were already deep connivances between Portuguese and Spanish societies. The diplomatic preparation of the integration, even before the announcement of the death of king D. Sebastian, shows that the perspective of a dynastic Iberian union could be considered as a possibility in political circles, profoundly inspired by the project of an universal catholic monarchy. Therefore, the representatives of the different bodies of Portuguese society only agreed to undergo the ceremony of voluntary union, in exchange for powerful warrants. On one hand a restrictive institutional mechanism, granted a complete jurisdictional immunity to the Portuguese kingdom as far as Castilian jurisdiction was concerned and on the other, the nobility, clergy and urban oligarchies had the opportunity to negotiate the settlement and increase of their privileges and benefits. It is within this context that the strategies for the control of power by the elites in Evora exerted by the Câmara and the Misericórdia must be understood.

In her study, Rute Pardal shows that the power wielded by the Câmara was manifest in its autonomy at the judicial, administrative and financial level, while the authority conferred to the Misericórdia was particularly visible in its capacity of receiving and dismissing its members, known as brothers. These two institutions had the freedom to manage their finances being only answerable to the king himself. Thus, the protection they received from the king, enabled them to eliminate competition from other 'brotherhoods': the autonomy enjoyed by those institutions was solely controlled by royal tutelage. 
The book is organised in three main chapters with an abstract that precedes the introduction. The nineteen annexes included at the end of the volume, contain the genealogy of the three aristocratic families of Évora, namely, the Counts of Tentúgal, Counts of Vimioso and Counts of Basto that in one way or other controlled local power. Annexes IV, V and VI, contain tables for the period 15801640 with the names of the men who had been elected for positions in both the Câmara and the Misericórdia in which as described by the author was a cursus honorum of a strategy to perpetuate individual and group power. Annexes VII, VIII, IX, X, XI and XII contain the statutes of the Misericórdia describing its rules in general and the particular functions that pertained to this institution, namely the election of its members, burials and travels undertaken by its members. The remainder of the Annexes are documents from the Câmara and comprise two letters from king Phillip II (I of Portugal) one written from Lisbon and the other written from Évora, four poems, one in the form of a lament to Portugal, and three satires in Spanish. The last Annexe is convocation from the Count of Basto.

Are the elites of Évora at the time of the Philippine domination part of the strategy for the control of the local power in the city? The author has successfully identified the structure of local power and reconstructed through the study of these two institutions the social make-up of the elites that wielded power. She has defined the strategies used by the ruling families for acquiring and retaining power. This they achieved not only during the sixty years of the Spanish rule but also during the political and social agitation in both the early and later years of the Habsburg reign in Portugal.

November 2007, Carmo Ponte

\section{Denis Rolland, Marcelo Ridenti, Elide Rugai Bastos (eds), L'Intellectuel, L'État, et la Nation : Brésil - Amérique latine - Europe, Paris, L'Harmattan, 2006, 290 p., ISBN : 2-296-00461-X.}

Ce volume contient quatorze articles partagés en trois parties, auxquels s'ajoute une courte introduction récapitulative. De qualités inégales, ils s'organisent le plus souvent autour d'un personnage ou d'un groupe historique spécifique. Les sujets ne sont pas inintéressants (d'autant plus qu'il n'est pas commun que se côtoient, comme ici, dans un même volume, cartographie, franc-maçonnerie, journalistes, cinématographes, musiciens, politiciens, anthropologues, et hommes de lettres). Ge qui pose problème, en revanche, est le manque de perspective critique par rapport aux outils conceptuels mobilisés pour les étudier. Ceux-ci restent tout au long en état d'a priori, ce qui donne aux meilleurs des chapitres des allures de bons récits, mais pas de recherche sérieuse. Tout particulièrement, le concept (et bien plus) de «modernité » est omniprésent dans l'ouvrage, sans qu'il ne soit jamais problématisé. Autour d'une thématique sur l'intellectuel-l'État-la-Nation, on peut voir pourquoi : la stabilité de ces termes-là est suspendue, finalement, à toute une série de postulats liés à une certaine vision de l'histoire, ce tramway nommé modernité. Le livre est une parfaite exposition du poids que pèsent les concepts et leurs grammaires sur une trame analytique : «la modernité », une sorte d'hyperconcept, 